\title{
OBSERVAÇÕES SÔBRE VIRA-CABEÇA EM TOMATEIROS
}

A. S. Costa

\section{INTRODUÇÃO}

A primeira referência sôbre a ocorrência desta moléstia em tomateiros (Lycopersicon esculentum Mill.), no Estado de São Paulo, foi feita por Bitancourt (4). Êste autor verificou que os tomates postos à venda, nos mercados da capital, se mostravam, em grande número, afetados por manchas concêntricas, semelhantes àquelas causadas pelo virus do "spotted wilt" (Lethum australiense H. var. Typicum H.).

Azevedo (1) publicou posteriormente um trabalho no qual descreve uma moléstia de virus do tomateiro, observada em plantas cultivadas no Jardim Botânico do Rio de Janeiro. Fazendo comparações entre essa moléstia e a causada pelo virus do "spotted wilt", o autor chega à conclusão de que não são idênticas. Como as diferença apontadas são apenas sintomatológicas, têm pouco valor como base diferencial.

Em um trabalho sôbre vira-cabeça do fumo (16) foi relatado que esta moléstia podia ser transmitida artificialmente para tomateiros. Estas observações foram confirmadas em trabalho posterior (6), sendo então descritos os sintomas apresentados pelas plantas que tinham sido inoculadas. Neste mesmo trabalho foi apontado que o virus de vira-cabeça seria provàvelmente idêntico ou pròximamente relacionado ao virus do "spotted-wilt". Posteriormente (7), reunindo a evidência experimental obtida em nossos estudos sôbre o virus de vira-cabeça, procuramos demonstrar aquela afirmativa.

Deslandes (10) descreveu uma moléstia do tomateiro em Pernambuco e atribuiu-a ao virus do "spotted-wilt". Como já foi dito, o virus de vira-cabeça pertence ao grupo do virus do "spotted-wilt", porém é preferível continuar a designá-lo por aquêle nome. É de se julgar que, tanto a moléstia descrita por Azevedo como aquela observada por Deslandes, sejam devidas a um virus provàvelmente não diferente do virus de vira-cabeça, existente em São Paulo. 


\section{SUSCETIVEIS}

Vira-cabeça é uma moléstia do tomateiro (Lycopersicon esculentum Mill.), do fumo (Nicotiana tabacum L.), da batatinha (Solanum tuberosum L.) e de numerosas outras Solanacex; também são afetadas plantas de outras famílias. O círculo de hospedeiras dêste virus já foi publjcado (7).

Não são conhecidas variedades comerciais de tomateiros satisfatòriamente resistentes ao virus de vira-cabeça. Sob as nossas condições, tĉdas as variedades se têm mostrado afetadas. Nos quadros I e II reproduzimos as observações efetuadas sôbre vira-cabeça em dois ensaios com cêrca de 30 variedades de tomateiros( ${ }^{*}$ ). Deslandes (10) ensaiou e observou 17 variedades quanto à sua resistência à moléstia, presente em Pernambuco, e tôdas se mostraram altamente suscetíveis.

Outros investigadores também têm experimentado dificuldades em encontrar variedades resistentes aos virus do grupo do "spotted wilt". Samuel, Bald e Pittman (23) estudaram 48 variedades de tomateiros em relação a "spotted-wilt". Nenhuma delas demonstrou possuir resistência satisfatória, mas a variedade "Early Dwarf Red" foi a que mostrou menor incidência da moléstia no período em que foi observada. Moore (19) ensaiou 10 variedades de frutos amarelos e vermelhos: nenhuma mostrou resistência apreciável a "Kromneck". As variedades ensaiadas foram: Santa Rosa, Beauty, Earliana, Ponderosa, Golden Queen, Best of All, Matchless, King Humbert, Mikado e Bide's Recruit. Sakimura (22) estudou as variedades Marglobe, Brak O' Day, Burbank, First Early, Globe, Ponderosa, Pritchara, Red Plum, Rutgers e Stone, quanto à resistêricia ao virus da mancha amarela do abacaxł. Tôdas elas se mostraram suscetíveis e os sintomas apresentados não variaram significantemente.

Lycopersicon pimpinellifolıum Mill., uma espécie selvagem do gênero, mostrou resistência ao virus do "spotted wilt" na Austrália $(22,3)$ e nos Estados Unidos. Sakimura (22) refere que L. pimpinellifolium é afetado pelo virus da mancha amarela do abacaxí, mas não faz referência à resistência. Em São Paulo, a mesma espécie se tem mostrado altamente resistente ao virus de vira-cabeça. Em ensaios realizados, além de $L$. pimpinellifolium, também $L$. hirsutum e certas estirpes de $L$. peruvianum mostraram resistência a vira-cabeça.

Híbridos $F_{1}$ efetuados entre L. pimpinellifolium e a variedade comercial Early Jewel mostraram-se também resistentes. As qualidades

(*) Ensaios efetuados pela Secção de Horticultura dêste Instituto. 


\section{QUADRO I}

ENSAIO DE VARIEDADES DE TOMATES

\begin{tabular}{|c|c|c|c|}
\hline$V A R I E D A D E(*)$ & $\begin{array}{l}\text { Percen- } \\
\text { tagem } \\
\text { de vira- } \\
\text { cabeça }\end{array}$ & $V A R I E D A D E$ & $\begin{array}{l}\text { Percen- } \\
\text { tagem } \\
\text { de vira- } \\
\text { cabeça }\end{array}$ \\
\hline 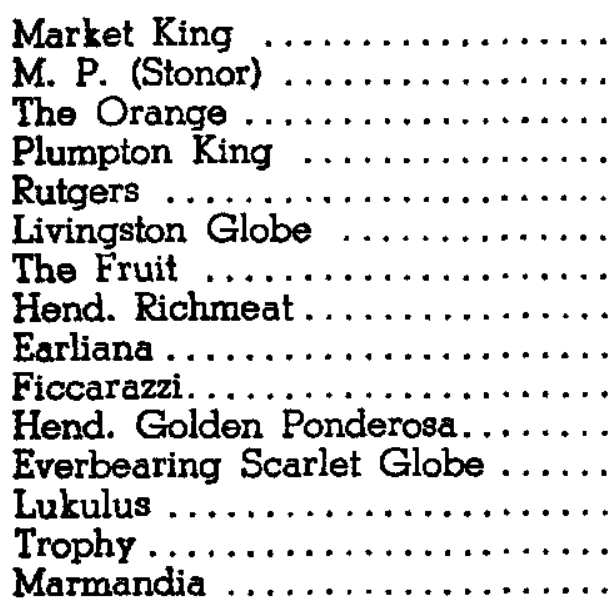 & $\begin{array}{r}3,6 \\
4,7 \\
7,5 \\
7,8 \\
10,3 \\
10,9 \\
11,4 \\
11,9 \\
12,3 \\
12,4 \\
13,0 \\
13,5 \\
13,8 \\
14,7 \\
14,7\end{array}$ & 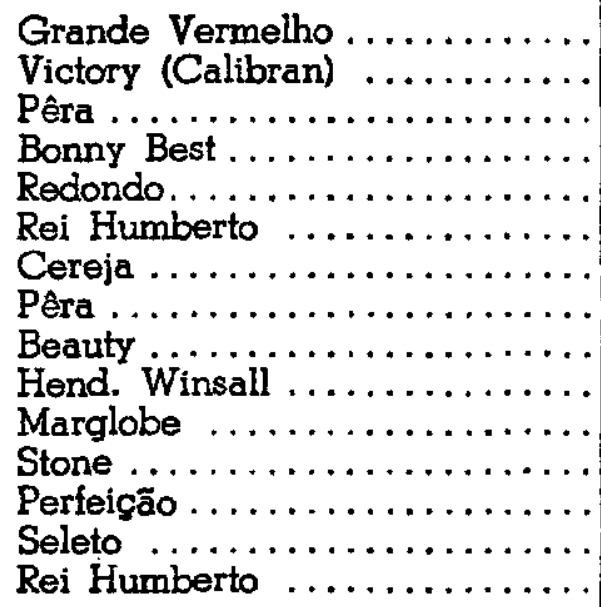 & $\begin{array}{l}15,9 \\
16,4 \\
17,4 \\
18,5 \\
20,5 \\
21,1 \\
21,5 \\
21,6 \\
24,9 \\
24,2 \\
25,5 \\
26,4 \\
27,1 \\
27,7 \\
39,7\end{array}$ \\
\hline
\end{tabular}

\section{QUADRO II}

ENSAIO DE VARIEDADES DE TOMATES

\begin{tabular}{|c|c|c|c|}
\hline V A R I E D A D E & $\begin{array}{l}\text { Percen- } \\
\text { tagem } \\
\text { de vira- } \\
\text { cabeca }\end{array}$ & $V A R I E D A D E$ & $\begin{array}{l}\text { Percen- } \\
\text { tagem } \\
\text { de vira- } \\
\text { cabega }\end{array}$ \\
\hline 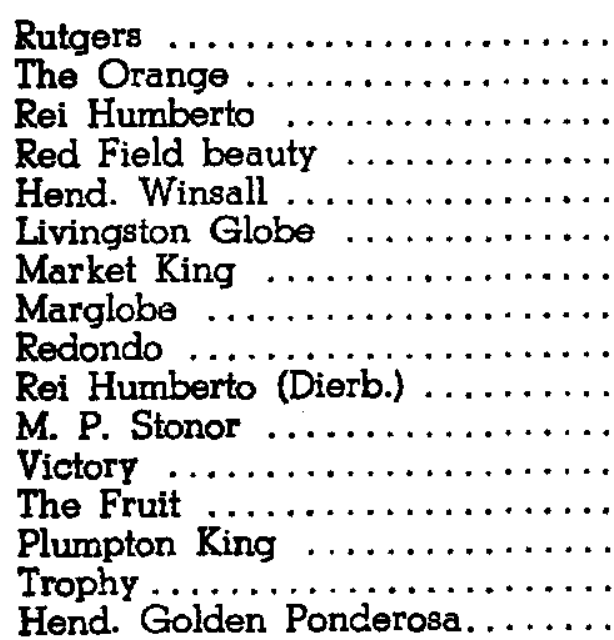 & $\begin{array}{l}3,8 \\
6,0 \\
6,4 \\
7,2 \\
7,6 \\
7,6 \\
7,8 \\
7,8 \\
8,0 \\
8,0 \\
8,0 \\
8,6 \\
9,0 \\
9,2 \\
9,2 \\
9,4\end{array}$ & 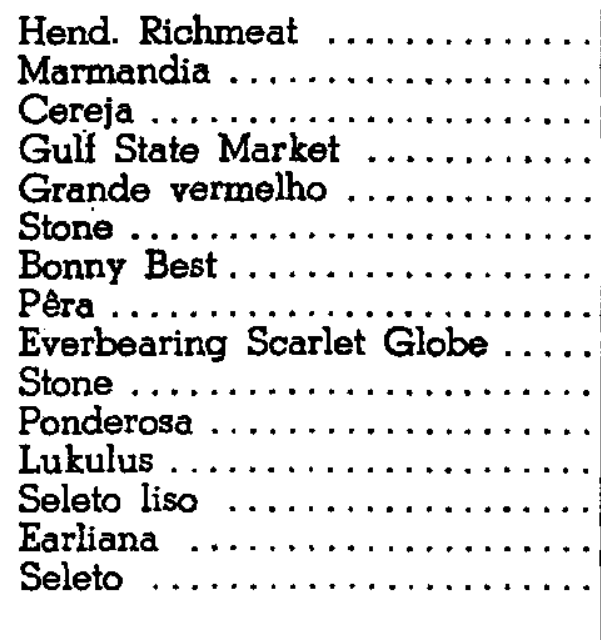 & $\begin{array}{l}9,6 \\
9,8 \\
10,6 \\
10,6 \\
10,8 \\
11,2 \\
11,4 \\
11,4 \\
12,0 \\
12,0 \\
12,4 \\
12,6 \\
12,8 \\
13,8 \\
14,0\end{array}$ \\
\hline
\end{tabular}

(*) Nome de registo da Secção de Horticultura do Instituto Agronômiobo do Estado em Campinas. 
do fruto são, porém, mais próximas àquelas de L. pimpinellifolium e, portanto, de nenhum valor comercial. Na figura 8 acham-se representadas três fileiras de tomateiros: A) L. pimpinellifolium; B) L. esculentum var. Early Jewel; C) Híbrido $F_{1}$ destas duas espécies. Vê-se na figura que tôdas as plantas da variedade Early Jewel foram mortas por vira-cabeça. Nenhuma planta de $L$. pimpinellifolium foi afetada e apenas uma planta do híbrido $F_{1}$ mostrou sintomas. Apesar de afetada, continuou desenvolvendo-se.

As qualidades comerciais do fruto do híbrido $F_{1}$ dêste cruzamento são más. Nas gerações seguintes nota-se o aparecimento de algumas plantas cujos frutos se aproximam mais da forma comercial. A seleção das plantas das gerações $F_{2}, F_{3}$ etc., tem sido encaminhada sempre para o lado das qualidades comerciais do fruto, levando-se em conta, ao mesmo tempo, o caraterístico resistência. Parece, entretanto, uma tarefa difícil conseguir êstes dois caraterísticos juntamente. Tem sido notado que há sempre perda de resistência quando as plantas selecionadas possuem frutos que se aproximam da forma comercial $\left({ }^{*}\right)$. Fato mais ou menos idêntico já havia sido relatado por Best (3), que tendo estudado L . pimpinellifolium sob as condições de campo na Austrália, verificou ser esta espécie resistente. No entanto, as possibilidades de melhoramento das variedades cultivadas de $L$. esculentum, a partir de cruzamentos com aquela espécie, não mostraram grandes probabilidades de sucesso.

\section{NOME E DISTRIBUIÇÃO GEOGRÁFICA}

Bitancourt (4) referiu-se à moléstia por êle observada sob o nome de murcha maculada. Devido à existência do nome vira-cabeça aplicado à doença do fumo causada pelo mesmo virus, é melhor aplicá-lo também para o caso do tomateiro. Além disso, o nome também é descritivo para a moléstia do tomateiro, pois as plantas afetadas apresentam, freqùentemente, como primeiro sintoma, o arqueamento para baixo das fôlhas das pontas de crescimento.

Vira-cabeça está espalhada por todo o Estado. A sua ocorrência em plantações de tomate já foi observada nas seguintes localidades: São Paulo, Cotia, Campinas, Itatiba, Valinhos, Ribeirão Preto, Tietê, Espírito Santo do Pinhal, etc. Vira-cabeça em fumo tem sido observada

(") A fim de aumentar o tamanho do fruto, tentou-se o tratamento das plantas selecionadas pela colchicina. Plantas das gerações $F_{1}, F_{2} \ominus F_{3}$ foram tratadas com sucesso, tendo sido obtidos alopoliplbides com $n=24$ e $n=48$. Também dos dois pais foram obtidos autopoliploides com $n=24$ e $n=48$. Nenhum dos poliplbides mostrou valor comercial. 
em numerosas outras localidades (9). Pode-se afirmar, sem receio de exagêro, que se encontra vira-cabeça em tôdas as localidades onde se planta o tomate ou fumo, neste Estado.

É muito comum encontrarem-se tomateiros afetados por vira-cabeça entre as plantas que nascem espontâneamente nos jardins ou em suas proximidades. Este fato parece indicar que o virus passa de alguma das plantas ornamentais suscetíveis para os tomateiros.

\section{IMPORTÂNCIA ECONÔMICA}

Em certas localidades e durante certas épocas do ano, vira-cabeça é indubitàvelmente a moléstia de maior importância na cultura do toma teiro. Nos lugares muito infestados torna-se muito difícil efetuar uma cultura satisfatória desta planta. Tal é o caso da Estação Experimental de Citricultura e da Estação Experimental Central em Campinas. Nestes dois lugares a percentagem de plantas afetadas pode subir a $100 \%$. Casos de ataques severos têm também sido observadòs em plantações de particulares. Na Fazenda São Pedro da Cascata, no município de Campinas, uma plantação efetuada em 1939 foi abandonada pelo seu proprietário, pois, logo de início, o número de plantas atacadas era tão grande que não compensava o trato. Em Taubaté, numa plantação de tomates feita em várzea de arroz foi observado um severo ataque desta moléstia. Deve-se também notar que, quando o protocolo desta plantação foi efetuado, cêrca de $20 \%$ das plantas já haviam sido arrancadas pelo lavrador, por se acharem afetadas. Foi, apesar disso, constatado que, em plantações de 79,66 e 53 dias de idade, a percentagem de vira-cabeça era de 5,2, 8,4; 17,2, respectivamente.

A importância econômica de vira-cabeça resulta do grande número de plantas mortas logo no início da plantação, ou então da grande diminuição da produção das plantas que conseguem sobreviver à moléstia. Além disso, quando as plantas são atacadas tardiamente, muitos frutos verdes exibem lesões necróticas, tomando-se impróprios para o consumo. Os frutos maduros mostram também lesões necróticas ou manchas desbotadas na côr, o que deprecia o seu valor.

\section{SINTOMATOLOGIA}

A sintomatologia de vira-cabeça em tomateiros é, assim como para o fumo, bastante variável. Entre os vários fatôres que influenciam a manifestação dos sintomas, podemos citar: a variedade, a idade em que a planta é afetada, as condições de vegetação da planta, o ambiente, a estirpe do virus, etc. 
Vira-cabeça pode manifestar-se em plantas de qualquer idade. Em certas ocasiões, já se podem observar plantas afetadas nas semen. teiras ou canteiros de repicagem. As plantas novas são muito suscetíveis à moléstia; à medida que aumentam em idade, vão adquirindo uma certa resistência. Em geral, a época crítica, em que a incidência da moléstia é maior, é a que vai desde a transplantação para o local defini. tivo até cêrca de 50 dias após.

\section{SINTOMAS DA MOLÉSTIA EM PLANTAS NOVAS}

As plantas novas afetadas têm o seu desenvolvimento paralisado. A côr verde normal das pontas de crescimento é alterada, perdendo o seu brilho. As fôlhas mais novas do tôpo da planta arqueam-se para baixo, ao mesmo tempo que os folíolos se enrolam para a parte superior (fig. 1). Muitas vêzes manifesta-se necrose ràpidamente nas fôlhas novas, não havendo então enrolamento dos folíolos; quando êstes se enrolam adquirem quase sempre uma tonalidade arroxeada em seus bordos. Foi observado que o sintoma - enrolamento dos folíolos - aparece na razão inversa da necrose : há mais tendência para enrolamento quando a necrose é fraca ou ausente. Os folíolos das fôlhas inferiores das plantas também se enrolam, sendo êste o único sintoma que apresentam. A necrose se manifesta não sòmente nas fôlhas novas, mas também nas partes novas da haste. Pode progredir de cima para baixo, respeitando, contudo, as partes mais inferiores. Não raro, todo o tôpo da planta ou a parte superior dos diversos galhos morre, apresentando uma forma de acronecrose.

tipo de necrose presente nas fôlhas manifesta-se sob diferentes formas (fig. 2), taís como: bronzeamento, anéis simples ou concêntricos com ou sem pinta central, riscas acompanhando as nervuras, etc. Em geral, em seguimento às lesões necróticas dos folíolos, aparecem a murcha e sêca. As lesões necróticas da haste (fig. 3) são deprimidas, de conformação variável ; em geral, alongadas no sentido longitudinal da haste. Em certos casos, observamos fôlhas que não mostram necrose nos folíolos, mas cuja nervura principal se torna inteiramente necrótica, de côr preta. Posteriormente, os folíolos de tais fôlhas amarelecem, murcham e secam.

Quando a necrose se manifesta em forma violenta, as plantas novas podem ser mortas pela moléstia; quando os sintomas não são muito severos, muitas plantas sobrevivem. $O$ crescimento de tais plantas é, a princípio, fraco, constituído por fôlhas subdesenvolvidas apresentando malformações, mosaico e encrespamento. Nesta fase, a planta apresenta, muitas vêzes, um tufo de vegetação na parte superior ("Bunchy 


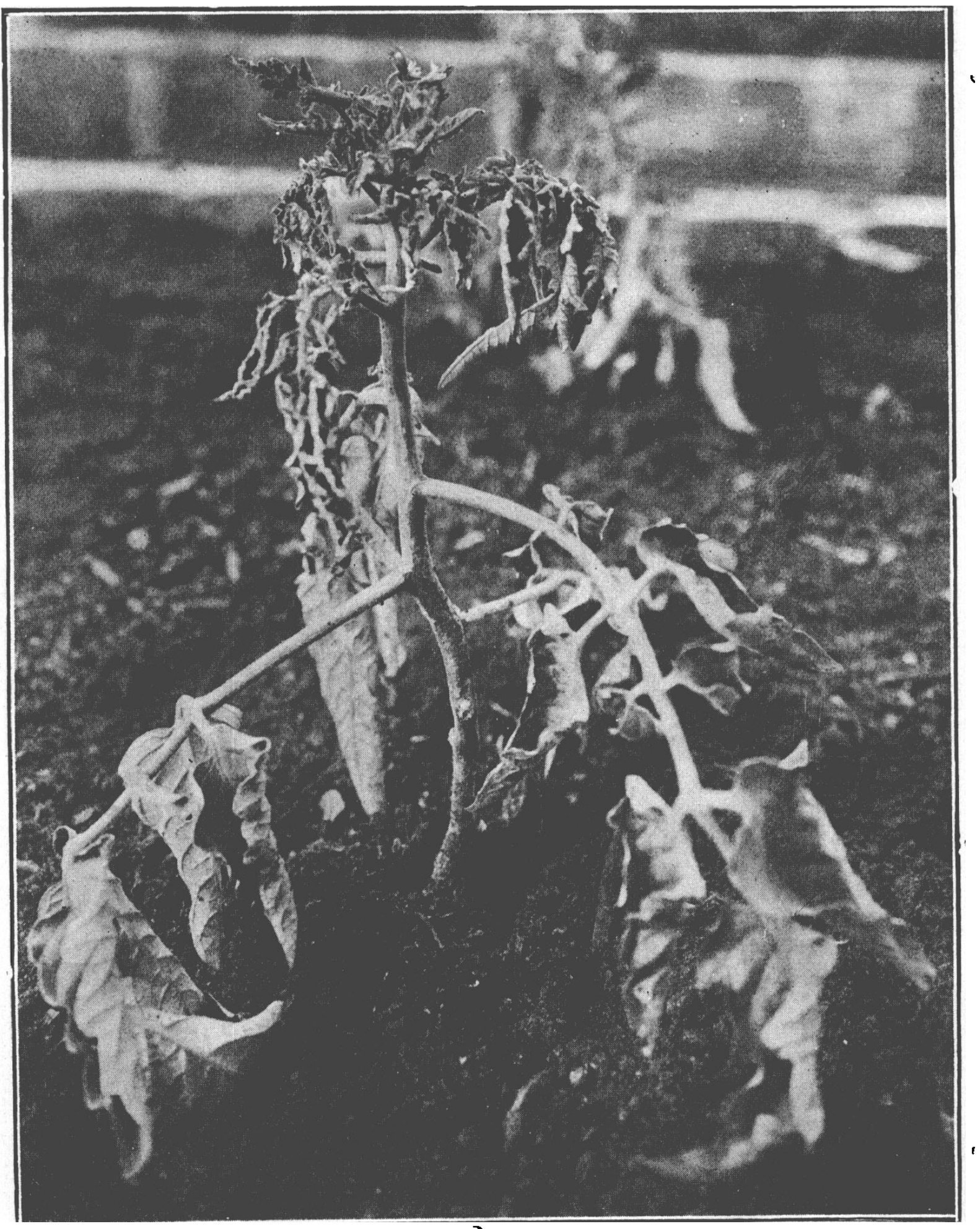

Figura 1 -. Planta afetada por vira-cabeça. Notar o arqueamento, dasifôlhas para baixo e enrolamento dos folíolos para cima. Na fotografia não se percebe a coloração arroxeada dos bordos. 

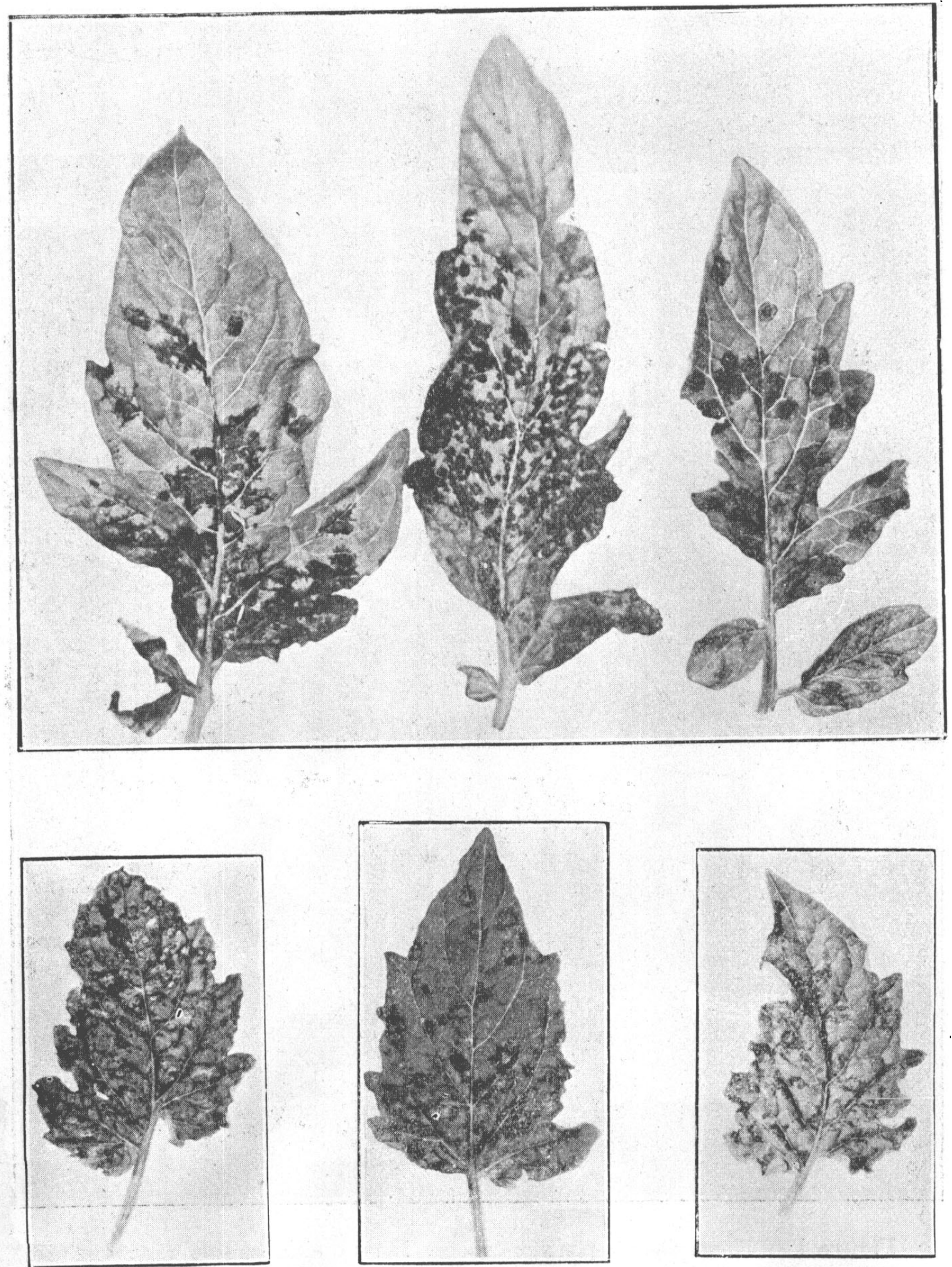

Figura 2 -- Tipos de nociuse presentes em folíolos de tonncileiro afetados por vira.
cabeça. 
top"). Êste tufo de vegetação é formado não só pelo crescimento apical, como também por aquêle proveniente de gemas axilares situadas nas proximidades do tôpo. Posteriormente, as fôlhas das pontas de crescimento vão perdendo os sintomas e chegam a apresentar uma aparência normal (restabelecidas).

\section{SINTOMAS EM PLANTAS ADULTAS}

Os sintomas iniciais apresentados por plantas adultas são idênticos àqueles já descritos, isto é, paralização no crescimento, arqueamento das fôlhas para baixo e necrose; enrolamento dos folíolos para a face superior é também uma feição constante da moléstia. A côr das fôlhas mostra uma tendência para se tornar amarelada, neste caso mais pronunciada do que nas plantas novas afetadas. A necrose, que a princípio se manifesta na parte superior, progride um pouco em direção descendente e manifesta-se também nas inflorescências e nos cachos de frutos. Os frutos podem apresentar lesões necróticas externas e internas. Necrose é comum nos frutos ainda verdes (fig. 4); as lesões são levemente deprimidas, de côr parda. A conformação destas é variada, sendo muitas vêzes do tipo de anéis concêntricos ou linhas paralelas. Frutos maduros mais raramente apresentam necrose (figs. 5 e 6); o tipo de sintoma nêles mais frequente consiste em manchas desbotadas da côr vermelha do fruto, às vêzes sob a forma de manchas amarelas em anéis simples ou concêntricos. Não é, porém, regra geral que os frutos de plantas afetadas mostrem sintomas. Muitas vêzes isto não se dá. Já notamos também plantas aparentemente sadias cujos frutos mostravam sintomas típicos de vira-cabeça.

\section{ETIOLOGIA}

Como já foi referido, esta moléstia é produzida pelo mesmo virus que causa vira-cabeça em fumo. Este fato tem sido provado por numerosas experiências de inoculações cruzadas. Ensaios efetuados para determinação das propriedades físicas das estirpes isoladas mostraram que elas são idênticas àquelas das estirpes provenientes de fumo (7). Frankliniella sp, vetor de vira-cabeça em fumo, é também vetor desta moléstia em plantações de tomateiros. É possível, porém, que alguma outra espécie de tripes possa também atuar como vetor.

Vira-cabeça é transmissivel mecânicamente sob condições artificiais. Êste modo de transmissão não tem, porém, importância alguma nia natureza. Mesmo sob condições experimentais é difícil obter transmissão mecânica do virus de vira-cabeça a partir de inóculo de plantas do campo, a despeito de se fazer uma escolha cuidadosa daquela que 
fornecerá o inóculo. No entanto, com o suco de plantas já infetadas artificialmente, torna-se mais fácil obter a transmissão. Em alguns casos foi observado um aumento na facilidade em ser transmitido mecânicamente, depois de o virus ter sido inoculado algumas vêzes sob condições experimentais. É possível que neste caso tenha havido uma espécie de seleção do virus neste sentido.

\section{OBTENÇÃO DO VIRUS DE VIRA-CABEÇA DE FRUTOS}

A obtenção do virus do "spotted wilt" a partir de tomates verdes foi relatada por Bald e Samuel (2). Smith (26) não pôde, porém, obter o mesmo virus de frutos maduros. Shapovalov e Dufrenoy (24) observam que o virus do "spotted-wilt" está presente nos frutos verdes afetados, mas que o suco dos frutos maduros não é infecioso. Paris (20) conseguiu também o virus da mancha amarela do abacaxí a partir do suco de tomates verdes de plantas afetadas; com $\circ$ suco de tomates maduros nunca obteve transmissão. Sakimura (22) também nota que o virus da mancha amarela do abacaxí, da mesma maneira que o virus do "spotted-wilt", não pôde ser recobrado de tomates maduros afetados.

Em experiências realizadas, o virus de vira-cabeça foi isolado diversas vêzes de tomates verdes ou parcialmente maduros que apresentavam sintomas de moléstia. É muito fácil obter êste virus de frutos verdes, mostrando sintomas necróticos severos. Já dos frutos com princípio de amadurecimento ou maduros, torna-se difícil obtê-lo, mesmo que se escolha para obtenção do inóculo aquêles que apresentam sintomas pronunciados.

Como já dissemos, nem sempre os tomateiros afetados pela moléstia exibem sintomas nos frutos. Já foram observados frutos com man. chas anelares caraterísticas de vira-cabeça em plantas aparentemente sadias. Caso semelhante foi também registado por Samuel (23) para o virus do "spotted-wilt".

Ainda está para ser verificado se os sintomas presentes nos frutos das plantas afetadas são causados pelo virus, que se tornou sistêmico na planta, ou se representam uma reação local a possíveis introduções do virus pela picada do vetor. A nosso ver, a forte reação necrótica dos frutos verdes é devida à invasão sistêmica do fruto; já no caso das man. chas anelares pode-se julgar serem elas devidas a picadas do vetor.

A obtenção do virus de vira-cabeça a partir dos frutos verdes é uma boa maneira de coletar êste virus das diferentes procedências. Em geral, fornece o virus numa forma pura e não oferece os inconvenientes das partes foliares que logo murcham e secam. 


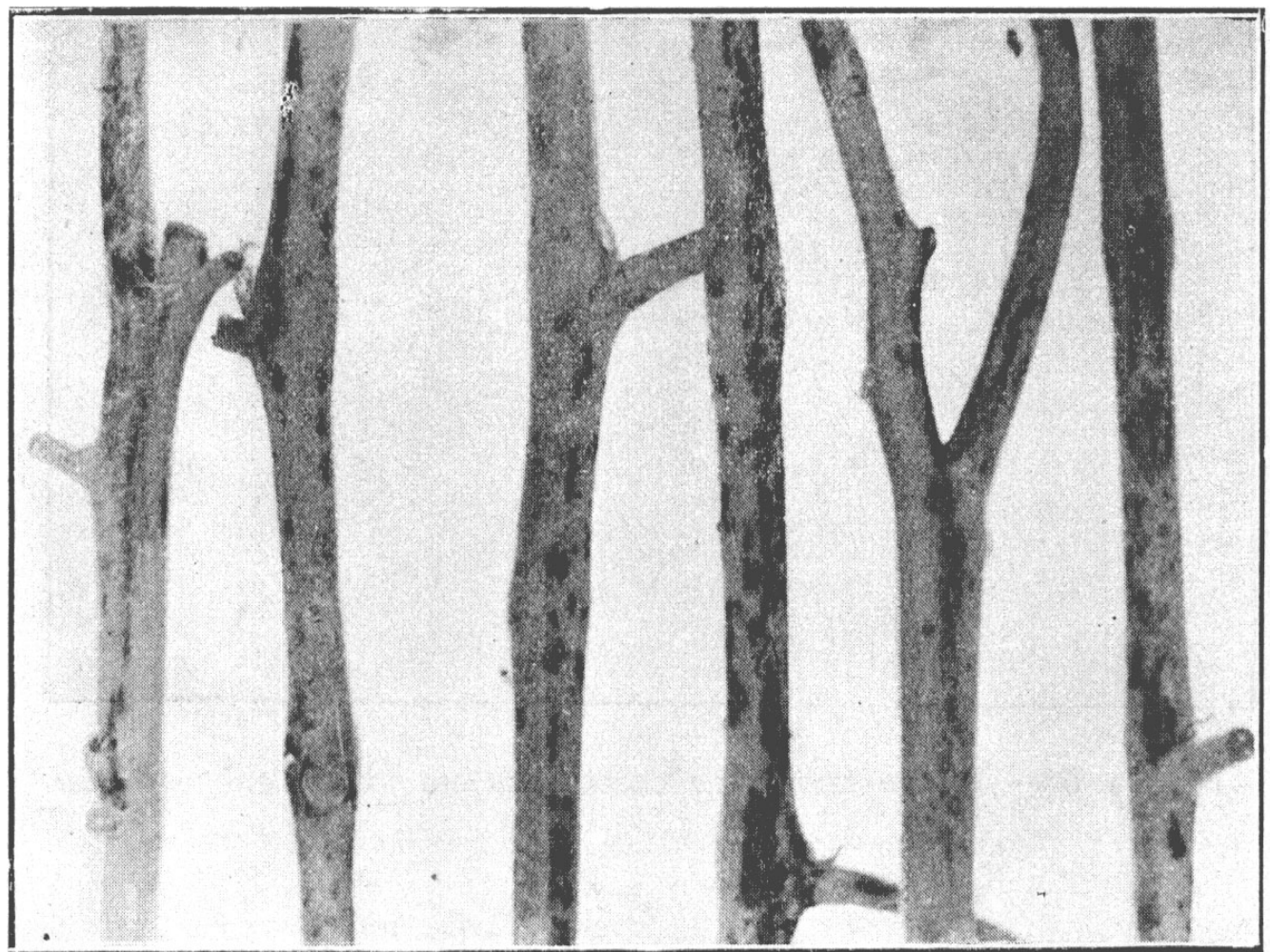

Figura 3 -..- Lesões necróticas observadas na parte superior das hastes de plantas afetadas.

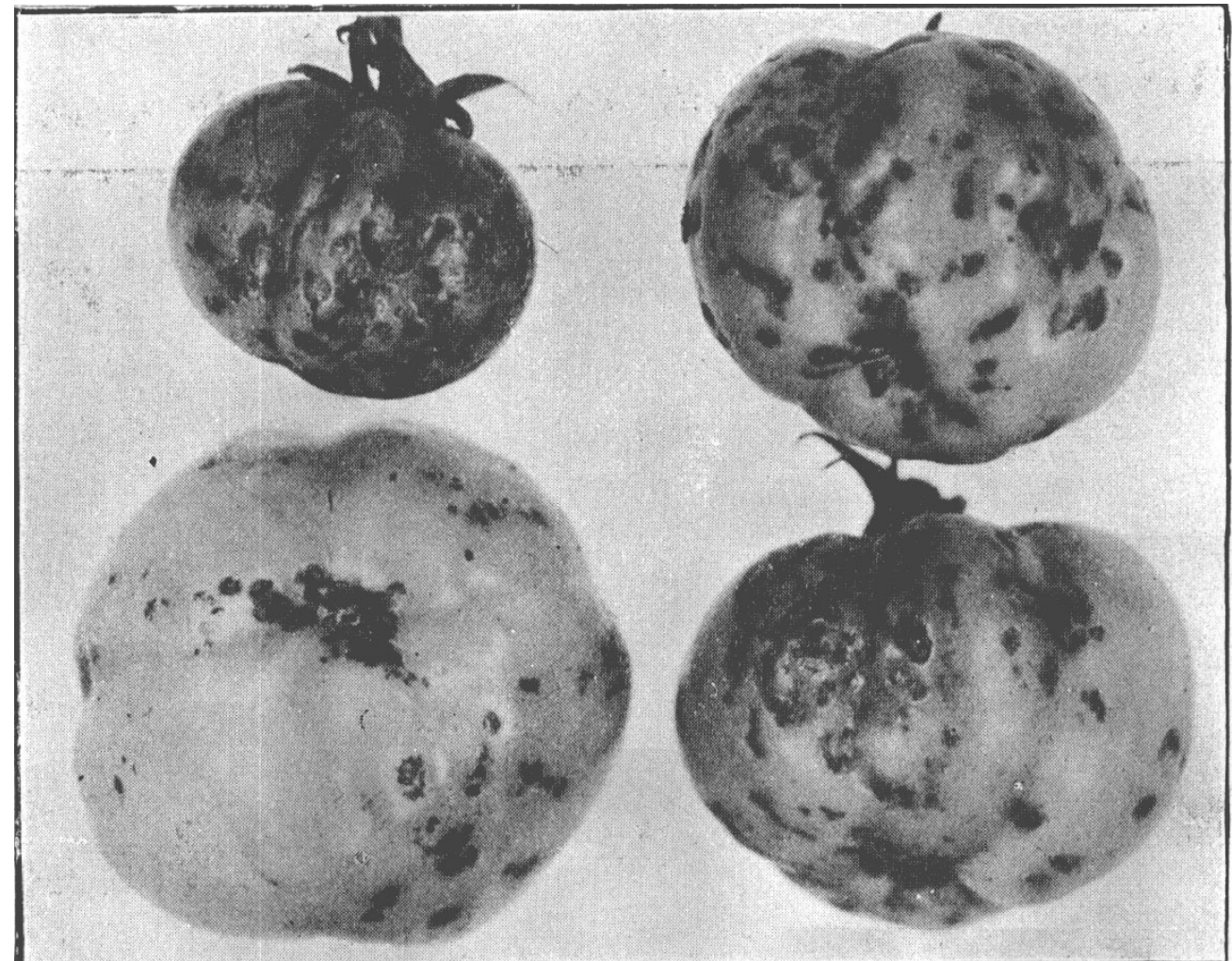

Figura 4 - Lesões necróticas observadas em frutos ainda verdes. 


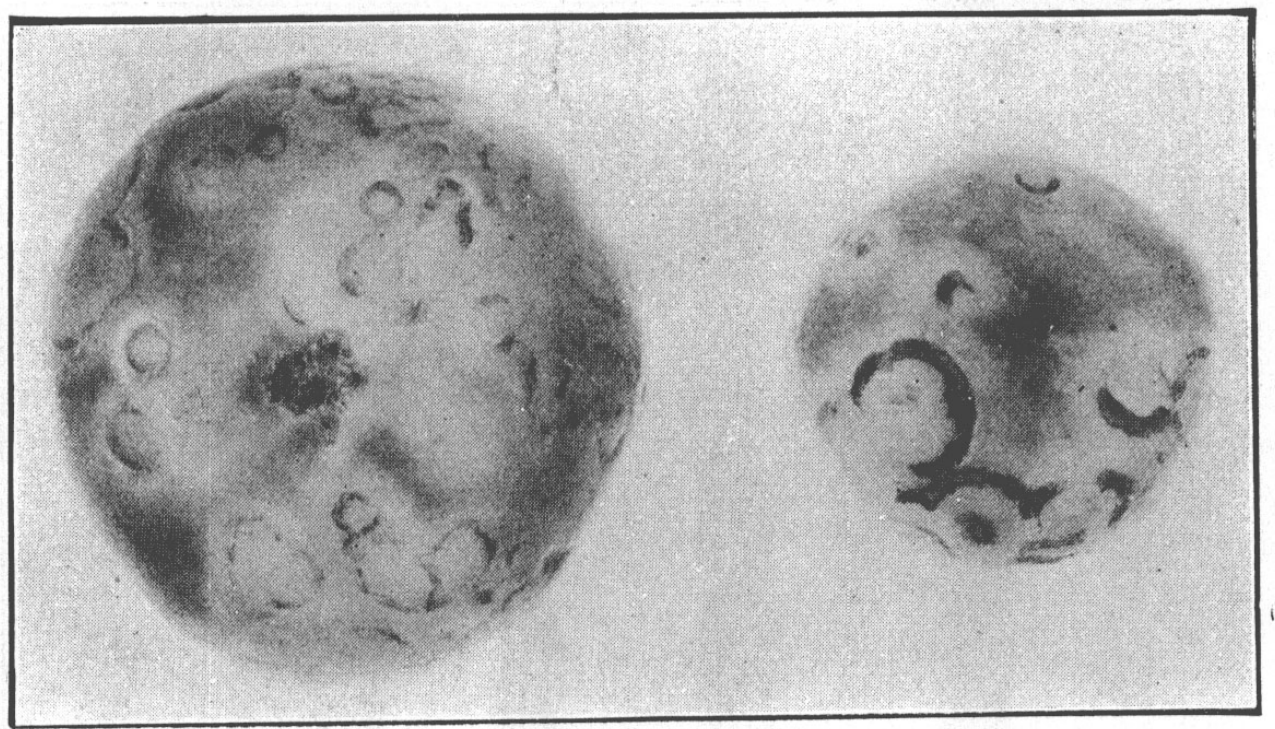

Figura 5 -.-. Lesões neróticas observadas em frutos semi-maduros.

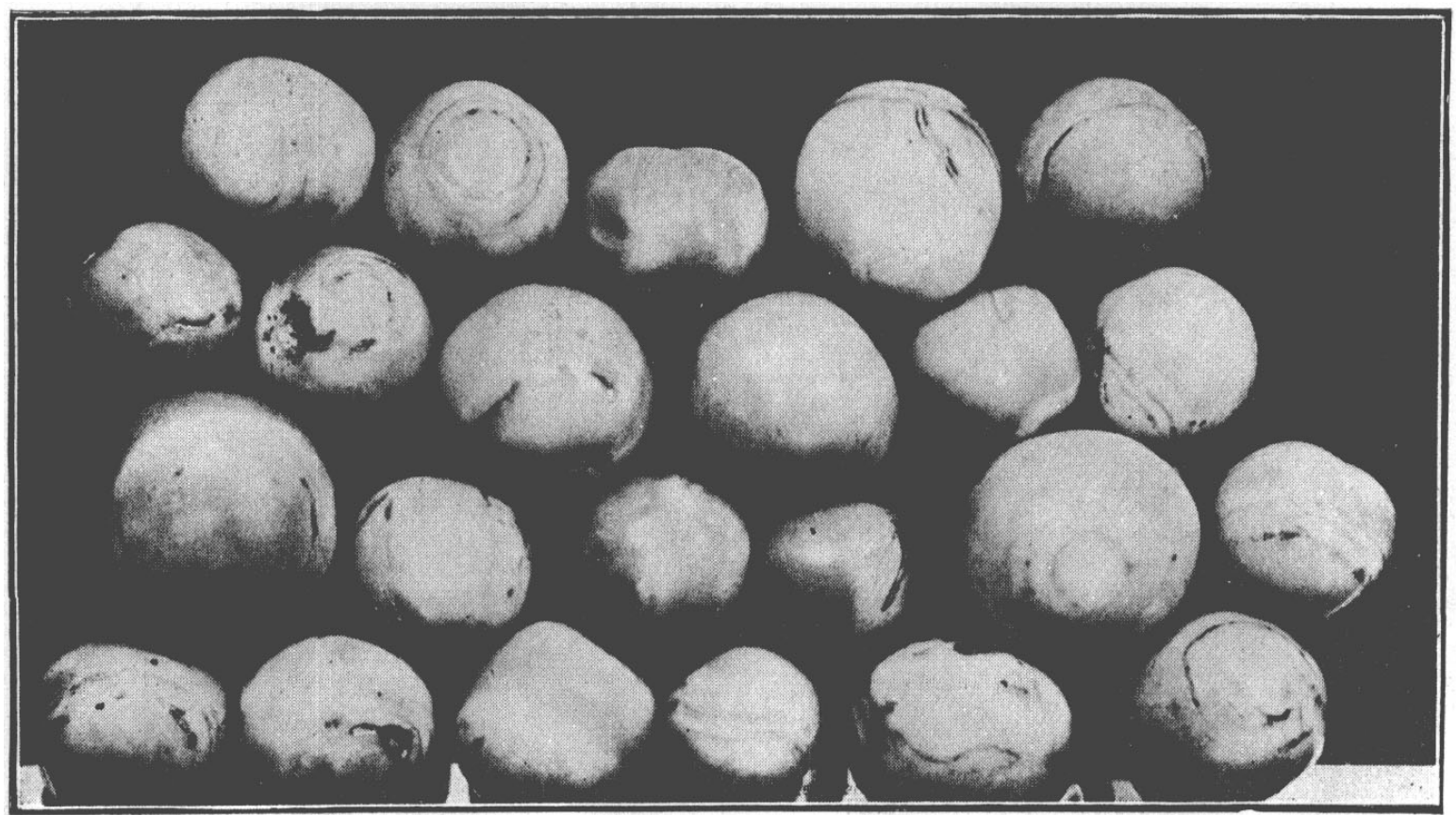

Figura 6 - Lesões nerróticas observadas em frutos semi-maduros. 


\section{O RESTABELECIMENTO DAS PLANTAS AFETADAS}

Assim como para o fumo, é bastante comum que tomateiros, que não são mortos pela moléstia, reiniciem o crescimento depois de algum tempo. A princípio, o novo crescimento é um tanto anormal, mas, em seguida, aparecem fôlhas aparentemente normais. Dá-se, portanto" o restabelecimento da planta ("recovery"). Há dois tipos principais de restabelecimento: o restabelecimento aparente, em cujo caso os tecidos das partes restabelecidas continuam a conter o virus, e o restabelecimerito verdadeiro, no qual o virus não está mais presente nos tecidos restabelecidos. O primeiro tipo é o mais comum, como, por exemplo, no caso do virus da mancha do fumo ("tobacco ring-spot virus") (21), no caso de virus de risca do fumo ("tobacco streak virus") (17) etc. O segundo tipo de restabelecimento já tinha sido observado com relação ao virus do "spotted-wilt" (25). Sob o ponto de vista de imunidade, há diferenças fundamentais entre os dois tipos. No caso do restabelecimento aparente, o virus continua presente nos tecidos e as partes restabelecidas não podem, em geral, ser infetadas novamente com estirpes do mesmo virus. No caso do restabelecimento em que 0 virus não está naaıs presente nos tecidos da planta, estas partes são tão suscetíveis como se não tivessem sido infetadas. Pelas seguintes maneiras, pudemos verificar que as partes restabelecidas de tomateiros, anteriormente afetados por vira-cabeça, não contêm o virus: 1) enxertias de plantas sadias com garfos de partes restabelecidas de plantas afetadas não transmitiram a moléstia ; 2) as partes recobradas foram inoculadas mecânicamente, mostrando-se então novamente afetadas; 3) partes restabelecidas foram multiplicadas por estacas e plaritadas num local infestado em comparação com estacas de plantas sadias. As plantas provenientes das estacas de partes restabelecidas não apresentaram nenhuma resistência.

\section{EPIFITOLOGIA}

O ambiente exerce um papel importante sôbre a incidência de vira-cabeça; influe diretamente sôbre a manifestação dos sintomas e desenvolvimento da moléstia $e$, indiretamente, sôbre a proliferação do inseto vetor. Sôbre a resistência da planta pròpriamente dita, não foi notada nenhuma influência do ambiente.

É sabido que em certas localidades, o ataque desta moléstia é menor do que em outras; isto pode ser conseqùencia direta do clima sóbre a proliferação do vetor ou ausência de fatôres que concorram para 
o aparecimento da moléstia, como hospedeiras nativas do virus, do vetor, etc. Numa mesma localidade existe uma grande variação na incidência de vira-cabeça de acôrdo com a época do ano. Na Estação Experimental Central em Campinas, o ataque de vira-cabeça em plantações de tomate ou fumo pode variar de menos de $5 \%$ a $100 \%$. A nosso ver, êste resultado depende principalmente da maior ou menor proliferação do inseto vetor. Aparentemente, a umidade parece ter maior importância a êste respeito do que a temperatura. Especialmente nas épocas sêcas do ano, ou algum tempo depois, é menor a incidência da moléstia. Em invernos úmidos já observamos casos de alta incidência de vira-cabeça.

Fawcett $(12,13)$ verificou que a sombra oferece uma certa proteção contra a "corcova" na Argentina, doença essa causada pelo mesmo virus que causa a "peste negra" do tomateiro naquele país. Está ainda para ser verificado se o efeito da sombra é sôbre a resistência da planta ou sôbre o vetor da moléstia.

\section{CONTRÔLE}

Não se conhece, até a presente data, nenhuma variedade de tomate resistente a vira-cabeça. A possibilidade de obtenção duma variedade resistente, a partir de cruzamentos com as espécies que mostraram resistência, é promissora, mas oferece, como já dissemos, muitas dificuldades. Estamos tentando obter a variedade criada por W. Porter a partir de cruzamentos entre $L$. pimpinellifolium x Marglobe, a que Blood (5) se refere como possuindo resistência ao virus do "spotted-wilt" ao lado de qualidades comerciais satisfatórias.

O arrancamento das plantas atacadas é uma medida aconselhável : deve ser feito quando a plantação é ainda nova e assim que as plantas principiem a mostrar os sintomas. Êste arrancamento é de pouca utilidade no caso de plantās já crescidas. As plantas arrancadas devem ser imediatamente colocadas dentro de um saco, e, posteriormente, enterradas ou jogadas muito longe da cultura. É desaconselhável arrancar as plantas afetadas e deixá-las no local.

É possível controlar-se o vetor de vira-cabeça nos viveiros de tomates. No campo isto já é muito mais difícil de ser executado. Em ensaios executados com fumo, verificou-se que o contrôle do vetor na fase do viveiro tem influência quase nula sôbre a incidência da moléstia em campo. Plantas de fumo criadas à prova de insetos, no viveiro, mostraram a mesma percentagem de vira-cabeça, em campo, que aquelas criadas em viveiro, sem nenhum contrôle do vetor. Se bem que isto tenha sido verificado para o fumo, é de se julgar que o mesmo aconteça quanto ao tomate. 


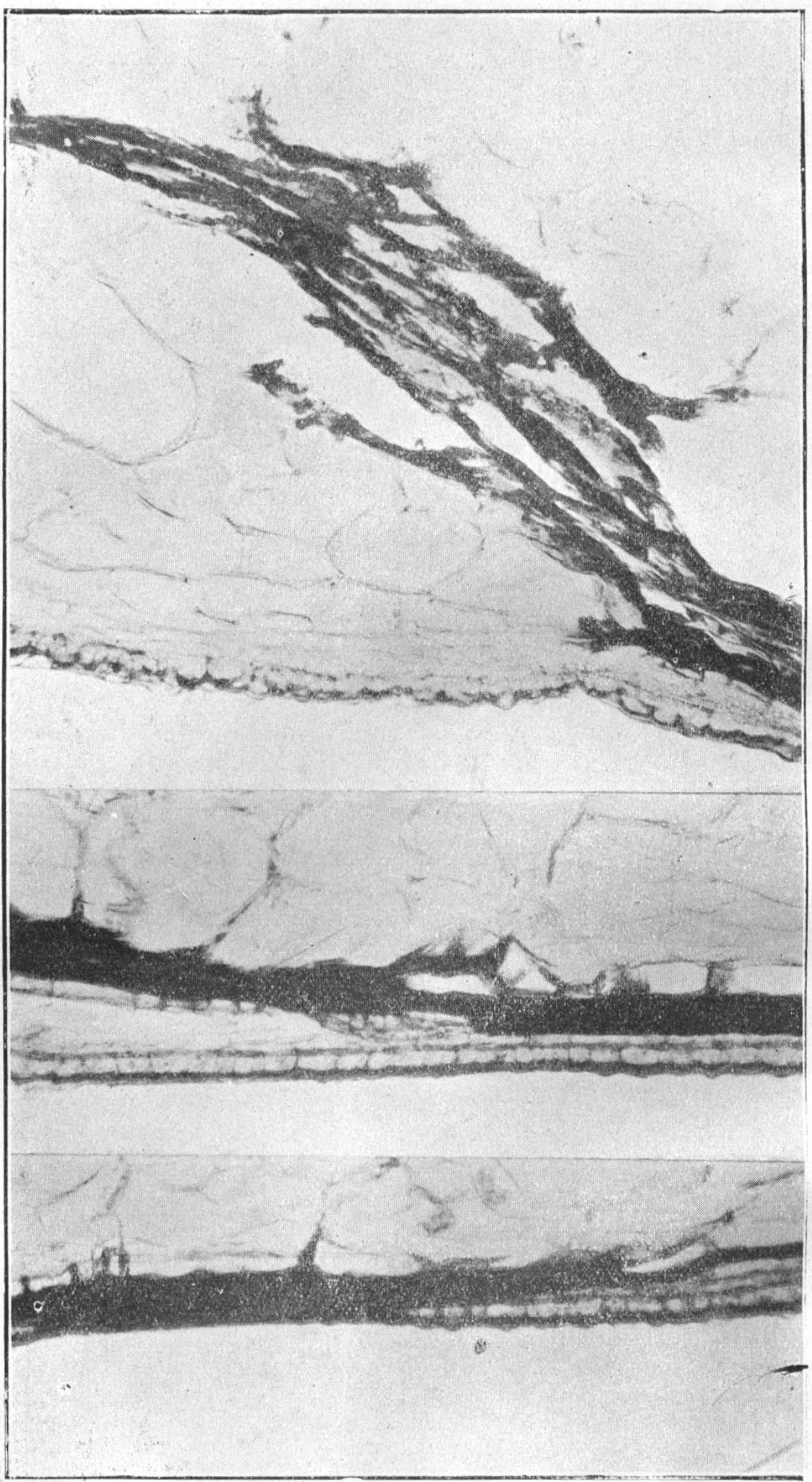

Figura 7 -- Cortes feitos em lesões necróticas do fruto. A necrose muitas vêzes não afeta a camada de células epidérmicas. 


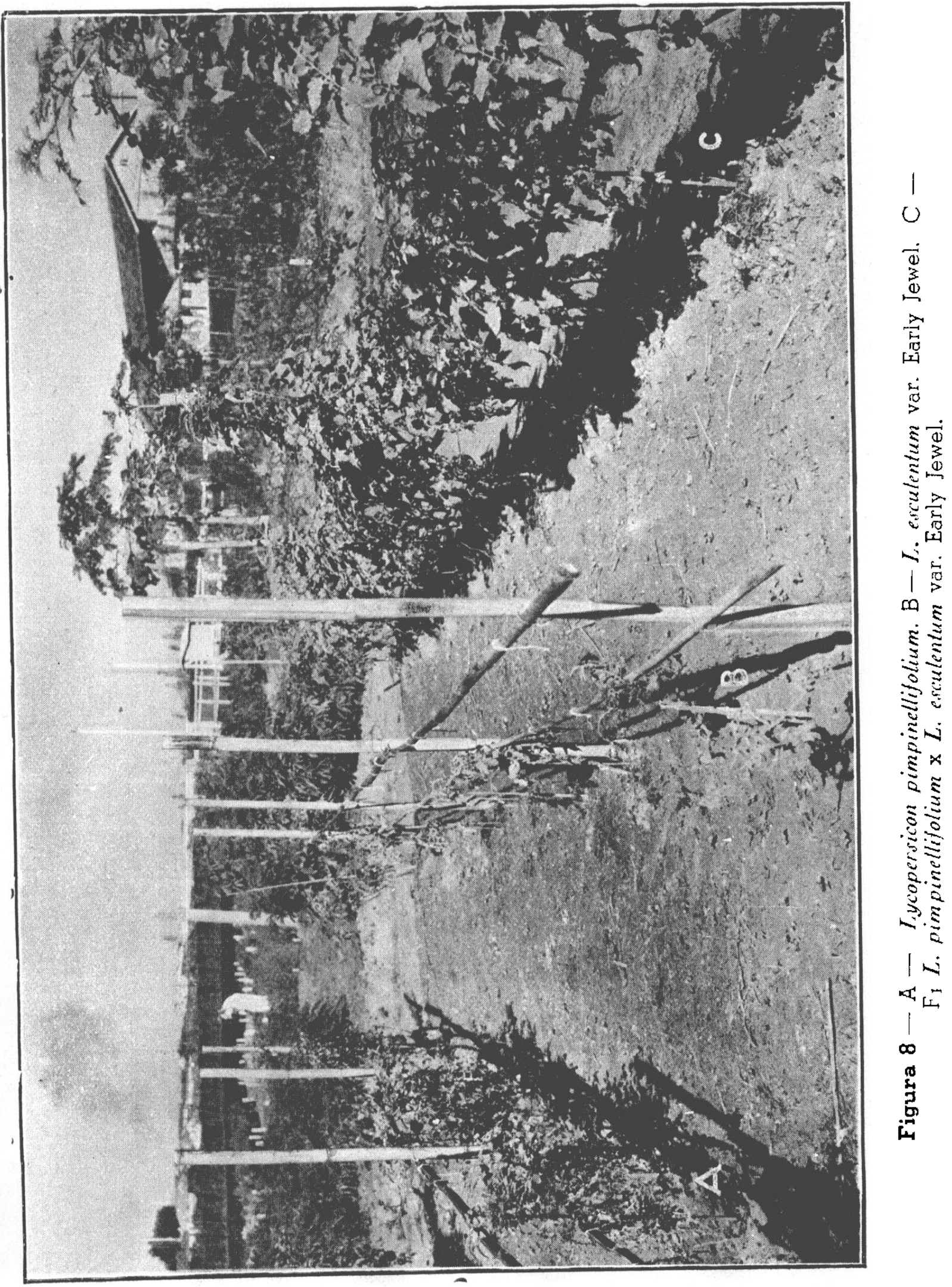


Apesar da pouca influência do contrôle do vetor de vira-cabeça no viveiro, sôbre a manifestação da moléstia em campo, deve-se efetuálo; pois, do contrário, arrisca-se a perder grande número de mudas que talvez venham a faltar na ocasião do transplante.

O contrôle do tripes, vetor de vira-cabeça, pode ser tentado pelo uso de inseticidas de contacto ou repelentes. Muitos inseticidas já têm sido ensaiados, em forma líquida ou em pó, no contrôle dos vetores das moléstias do grupo do virus do "spotted-wilt". Fawcett (11) empregou preparações de derris e sulfato de nicotina no contrôle da "corcova" do fumo na Argentina, mas os resultados foram negativos. Um certo contrôle da moléstia foi obtido pelo uso de arseniato de chumbo (14). O mesmo autor (15) verificou que o uso do enxofre molhável não deu bons resultados no contrôle da peste negra dos tomates na Argentina, enquanto a cal misturada com óleo, para melhor espalhar-se, forneceu bons resultados. Recentemente, Magee e Morgan (18) relataram que tinha sido obtido, pela pulverização com tártaro emético, o contrôle dos vetores do virus "spotted-wilt" na Austrália - Frankliniella insularis e Thrips tabaci, em plantações de tomates. As pulverizações foram feitas duas vêzes por semana no viveiro, e uma ou duas vêzes por semana na plantação. A formula usada no viveiro foi a seguinte:

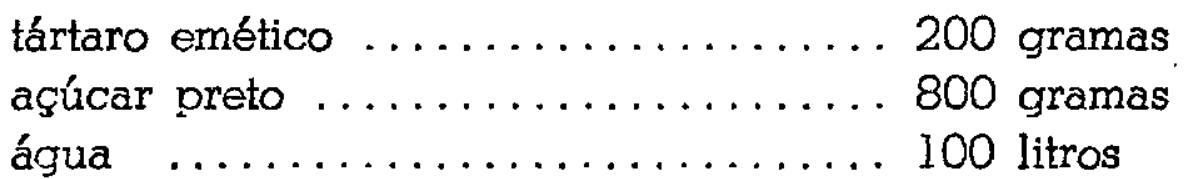

Nas aplicações feitas em culturas, no campo, a dosagem de tártaro emético pode ser dobrada.

$\mathrm{O}$ emprêgo de inseticidas, para o contrôle dos vetores de viracabeça na plantação, deve ser efetuado durante os primeiros 30 ou 40 dias após a transplantação. Uma vez passada esta época crítica, as plantas já se acham um tanto desenvolvidas, tendo adquirido certa resistência à moléstia.

Tem sido verificado que varia a incidência de vira-cabeça nas diferentes zonas do Estado. Bragança, São Bento do Sapucaí e Limeira são regiões onde a incidência da moléstia é menor do que em Campinas, Tietê ou Piracicaba. A escolha de localidades onde a moléstia não seja muito prevalente é uma medida aconselhável.

Uma das maneiras mais eficientes de controlar vira-cabeça é a escollha da época adequada de transplante. Mesmo na Estação Experimental Central em Campinas, onde a percentagem de vira-cabeça freqùentemente se aproxima de $100 \%$, épocas há durante as quais a

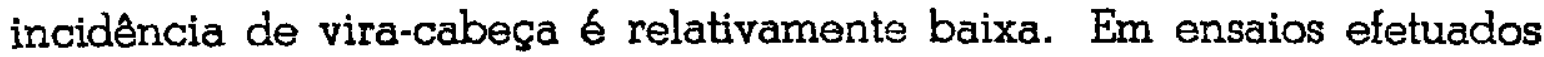


com fumo tem sido verificado que as épocas mais favoráveis de transplante, em relação a vira-cabeça e durante as quais as plantas podem desenvolver-se satisfatòriamente, coincidem com o início e fim da estação das chuvas. Setembro ou outubro, conforme as chuvas começam cedo ou mais tarde, e fevereiro e março são as épocas melhores. Êstes dados foram obtidos para o fumo, mas devem valer também para o caso do tomate. Durante os meses de inverno, a incidência de vira-cabeça pode ser baixa, mas, além da falta de água necessária para o crescimento das plantas, há também o perigo da geada.

A plantação de diversos lotes de tomates, um em seguimento a outro, é desaconselhável. Os insetos e moléstias das plantações prévias vão passando para as seguintes, infestando-as desde o início. Caso devam ser feitas plantaçc̃es seguidas, deve-se procurar localizá-las umas longe das outras; o mesmo podemos dizer para os viveiros.

\section{LITERATURA CITADA}

1. Azevedo, Nearch. Observaçc̃es sôbre uma doença de virus do tomateiro. Rodriquesia 6 : 209-212, pl. 1-8. 1936.

2. Bald, J. G. G. Samuel. Investigations on spotted-wilt of tomatoes. II. Counc. Sci. and Ind. Res. Australia. Bull. 54 : $1-24.1931$.

3. Best, R. J. Investigations on Flant Virus Diseases. Em Report of the Waite Agr. Inst. 1933-36 : 84-90. 1937.

4. Bitancourt, A. A. A mancha anular do tomate. O Biol6gico 2 : 98-100, fig. 1. 1936.

5. Blood, H. L. Breeding technique for disease - resistant tomatoes. Study of suitable plant varieties for Pacific Coast and Intermountain States. West. Cann. Pack. 31 : 50. 1939. Ref. Plant Breeding abstracts. 9:477. 1939.

6. Costa, A. S. e R. Forster. A transmissão mecânica de vira-cabeça por friç̧ão com suco. Rev. Agricultura $13: 249-262$, fig. 1-13. 1938.

7. Costa, A. S. e R. Forster. A identidade do virus de vira-cabeça e sua inclusão no grupo do "spotted-wilt". Bragantia 1: 491-516, fig. 1-19. 1941.

8. Costa, A. S. e R. Forster. Lista de hospedeiras do virus de vira-cabeça. Bra. gantia $2: 83-92.1942$.

9. Costa, A. S. $\theta$ outros. Contribuição para o conhecimento da distribuição geográfica das moléstias de fumo no Estado de São Paulo. Rev. Agricultura 17 : 237-256. 1942.

10. Deslandes, Josué A. Doenças do tomateiro no Nordeste. Bol. Sociedade Brasileira Agronomia 3 : 443-452. 1940.

11. Fawcett, G. L. Enfermedades del tabaco y de los tomates. Em Memoria anual del ano 1933. Rev. Ind. y Agric. Tucuman $24: 35-36.1934$.

12. Fawcett, G. L. Tabaco. Fim Memoria anual del ano 1934. Rev. Ind. y Agric. Tucuman 25: 153-154. 1935.

13. Fawcett, G. L. Enfermedades del Tabaco. Em Memoria anual del ano 1936. Rev. Ind. y Agric. Tucuman 27 : 31-32. 1936.

14. Fawcett, G. I. Enfermedades del tomate Y del tabaco. Em Memoria anual del ano 1933. Rev. Ind. y Agric. Tucuman $29: 37-38.1939$.

15. Fawcett, G. L. Enfermedades de los tomates. Em Memoria anual del ano 1941. Rev. Ind. Y Agric. Tucuman 32 : 41-45. 1942. 
16. Foretor, R. @ A. S. Costa. Nota preliminar sôbre a moléstia vira-cabeça do fumo. Rev. Agricultura 13 : 69-78, fig. 1-8. 1938.

17. Johnson, J. Tobacco streak, a virus disease. Phytopathology $26: 285-292.1936$.

18. Magee, C. J., W. L. Morgan e A. N. Johnston. Control of spotted-wilt of to" matoes. J. Aust. Inst. Agric. Sci. 8 : 115-117. 1942.

19. Moore, E. S. The Kromneck or Kat River Disease of Tobacco and tomato in the East Province (South Africa). Union of South Africa Dept. of Agri. Sc. Bull. 123: 1-28. 1933.

20. Parris, G. K. Mechanical transmission of yellow spot virus : evidence for identity with spotted-wilt virus. Phytopath. $30: 299-312.1940$.

21. Pxice, W. C. Acquired immunity to ringspot in Nicotina. Contrib. Boyce Thompson Institute 4 : 359-403. 1932.

22. Sakimura, K. Evidence for the identity of the yellow-spot with the spotted-wilt virus; experiments with the vector, Thrips tabaci. Phytopathology 30 : 281-299. 1940.

23. Samuel, G., J. G. Bald e H. A. Pittman. Investigations on spotted wilt of tomatoes. Counc. Sci. and Ind. Res. Australia. Bull. 44 : 1-64. 1930.

24. Shapovalov, IM. e J. Dufrenoy. Un virus infectant des Solaneés et des plantes d'ornament dans le sud-ouest de la France. C. R. Soc. Biol. Paris 123: 696-698. 1936.

25. Smith, K. M. Studies on potato virus diseases. VIII. On a ring spot virus affecting solanaceous plants. Arin. Appl. Biol. 18 : 1-15. 1931.

26. Smith, K. M. Studies on Plant Virus Diseases. XI. Further experiments with a ring-spot virus : its identification with spotted-wilt of the tomato. Ann. Appl. Biol. 19 : 395-430. 1932. 